\title{
Collection Management and the Budget Crunch: Are We Adequately Preparing Library Students for Current Practices?
}

\author{
Olivia Hedlund \\ Andrea Copeland, $\mathrm{PhD}$
}

2013

Collection Building, 32(4), 128-132.

Authors' accepted manuscript. Final published version available at: http://dx.doi.org/10.1108/CB-032013-0012 
Olivia Hedlund

Andrea Copeland, PhD

School of Informatics and Computing

Department of Library and Information Science

Indiana University

755 W Michigan Street, UL3100C

Indianapolis, IN 46202

Title: Collection Management and the Budget Crunch: Are We Adequately Preparing Library Students for Current Practices?

\section{Introduction}

In an ideal world professional practice, library associations' standards and library education would reflect one another. For many aspects of library science education, professional standards are abundant. However, with regards to collection development and management practices there are few actual standards dedicated solely to collection development practices. Three guidelines are available from the RUSA site: writing reviews, liaison relations, and bibliography preparation. In 2013, the RUSA CODES Collection Development Planning, Education \& Assessment Committee will undertake revising ALA's Guide to Collection Development Policy Statements from 1996. This version is not on the web as yet. Other guidelines and standards, for example, ALSC's Competencies for Librarians Serving Children in Public Libraries and RUSA's Professional Competencies for Reference and User Services Librarians cover only some aspects of collection development and management.

As a member of the aforementioned committee, one of the authors began to wonder what factors should be considered in the revision of such a document. How should this revision reflect curriculum, textbooks in the area and trends in practice? In other words how this revision could best achieve the ideal state of reflecting professional standards, LIS education, and actual practice. Such a revision, capturing both foundations of professional practice and current trends in the field (including those related to economic conditions), could be useful for not only professionals but also LIS educators and students.

Libraries of all types have been struggling with materials budgets for many years and especially so in the recent economic recession. As a result, libraries have developed a number of strategies for dealing with budget constraints. The professional literature provides many examples of what collections librarians are doing to cope with the budget constraints, for example,

Authors' accepted manuscript. Final published version available at: http://dx.doi.org/10.1108/CB-03$\underline{2013-0012}$ 
cooperative collection building (Collins 2012; Kieft and Payne 2012; Pan and Fong 2010; Nous and Roslund 2009), patron driven acquisitions (PDA) (Fisher, Kurt and Gardner 2012; Herrera 2012; Sammonds 2012; Schroeder 2012; Schroeder and Wright 2011), and floating collections (Johal et al. 2012).

In addition to considering the strategies for inclusion in the revision of the guide to collection policies, the authors wanted to see if these strategies are included in LIS curriculum. LIS educators who teach collection-related courses were surveyed in an effort to understand the influence of these practices on curriculum and to encourage a unity among practice, teaching and professional standards.

\section{Literature Review}

Many studies have examined the influence of practice on LIS curriculum. This usually takes the form of evaluating curriculum for evidence that supports professional standards, as well as surveying library educators, students and practitioners. Domain areas covered include reference, instruction, school media, and general accreditation standards. There are no existing studies that look specifically at collection management education, practice and professional guidelines. Several studies discussed below illustrate the importance of connecting the three aspects of professional education and development.

In an overarching study, Lester and Van Fleet (2008) examined the use of professional competencies and standards documents by LIS educators for curriculum planning, by public library directors for hiring and professional development decisions, and by state library development officers for certification requirements and developing professional education. A content analysis of program presentation documents submitted to the American Library Association Committee on Accreditation revealed that LIS educators do use these standards in curriculum. However, a survey of directors and development officers found that these individuals use these standards much less than LIS educators and found them less useful. A study by Mon et al (2008) explored the state of remote reference services in the United States by describing remote reference availability at 100 public libraries, examining remote reference in the syllabi of LIS courses, and analyzing national competencies and guidelines. They found that the telephone was most commonly used for remote reference services at public libraries, followed by e-mail and chat. Interestingly, syllabi at LIS programs addressed digital reference media more often than the telephone. Professional standards and guidelines focused on general

Authors' accepted manuscript. Final published version available at: http://dx.doi.org/10.1108/CB-03$\underline{2013-0012}$ 
practices relevant to both remote and face-to-face reference work, rather than standards related to each of different remote reference media types.

Two studies are related to school media specialization. Everhart and Dresang (2007) used the National Board for Professional Teaching Standards to successfully enhance their curriculum related to one specific aspect of the curriculum, organizational leadership. Their research included interviewing five unsuccessful school librarian job candidates and surveying 353 successful candidates to validate changes to the curriculum and to improve it further. Conversely, Church, Dickinson, Everhart, and Howard (2012) examined a multitude of professional and state standards that apply to school media specialization. They found that these standards are too numerous and at times contradictory to include all applicable standards in the curriculum and that while themes overlap priorities must be made with regards to which standards to include.

Increasingly, academic library positions have responsibilities for library and information literacy skills instruction. Sproles, Johnson, and Farison (2008) explored how well LIS programs are preparing academic librarians for instructional roles. From the review of reference syllabi, they found that at 39 of the 45 MLIS programs they surveyed reference is a required course and the topic of instruction is included in 26 of the required classes. Further 46 of the 54 program had separate courses in instruction. In 2007, ACRL published the Standards and Proficiencies for Instruction Librarians and Coordinators. The instruction course syllabi were examined for inclusion of the 12 proficiencies of the ACRL document. Most of the syllabi emphasized proficiency in instructional design and teaching methods while understating proficiencies related to leadership, administration and assessment skills.

Considering the aforementioned studies that made use of or found professional standards useful in a variety of library environments, we return to the discussion of collection development standards. It is important to note that many of the professional standards for collection development that are available, such as ALA's Guide to Collection Development Policy Statements (published in 1996), are very outdated and do not address new collection development trends such as those related to recent economic strain. With few relevant, current professional standards to turn to, the authors wondered how educators of collection development form the curricula they use to educate future LIS professionals.

The present research provides a fresh perspective on LIS education in that it examines current trends in the practice of collection development and whether or not they are represented in LIS

Authors' accepted manuscript. Final published version available at: http://dx.doi.org/10.1108/CB-03$\underline{2013-0012}$ 
curriculum and how they might or should influence professional guidelines. It may help inform aforementioned committee's updating the Guide to Collection Development Policy Statements as well as highlight new collection development trends that should be considered for inclusion in the LIS curriculum. Further, this paper adds the domain of collection development to the discussion of LIS courses influenced by practice.

\section{Research Question}

Are current collection management practices that have evolved as a result of budgetary constraints included in LIS curriculum?

\section{Methods}

Numerous literature searches were conducted to identify strategies librarians are using to deal with budget constraints. Databases used include Library and Information Science Abstracts (LISA) (ProQuest), Library Literature \& Information Science Full Text (EBSCO), Library, Information Science \& Technology Abstracts (LISTA) with Full Text (EBSCO), and Academic Search Premier (EBSCO). Search terms used included collection development, collection management, acquisitions, budget, funding, trends, and more.

After reviewing the literature the authors composed a survey consisting of both closed-and open-ended questions to be sent to instructors of collection development. The survey itself consists of five questions, with a final optional sixth question that allowed participants to leave contact information for survey tracking purposes (see appendix 1 for complete survey).

Potential participants for the study were solicited from institutions that are members of ALISE, the Association for Library and Information Science Education (this page lists all the member institutions: http://www.alise.org/index.php?option=com content\&view=article\&id=379). Potential individual participants were then identified using course and faculty listings on institution websites. Faculty, adjunct faculty, or instructors who had taught collection development related courses were identified and then contacted via email. The email explained the purpose of the study and included a link to participate in the study. Seventy-two potential participants were identified and contacted via email. The survey was available January $16^{\text {th }}$ through February $1^{\text {st }}$ of 2013. Thirty-five individuals completed the survey, for a response rate of $48.6 \%$. Results of the survey were analyzed using descriptive statistics and content analysis.

Authors' accepted manuscript. Final published version available at: http://dx.doi.org/10.1108/CB-03$\underline{2013-0012}$ 


\section{Participants}

The 35 participants represented a wide range of years of experience teaching collection development related courses. For several, this was their first term teaching collection development related courses; others had taught the course upwards of 35 years. Eleven had taught collection development courses for three or fewer years, nine had taught between five and nine years, nine had taught between 10 and 15 years, five had taught for 20 plus years, and one for 35 plus years.

Thirty-three of the participants had worked as practicing librarians, 1 had not, and one declined to answer. Years of librarian experience ranged from zero to thirty plus years. Library settings also varied widely and included school media, public, academic, special, Army, medical, and law libraries.

\section{Limitations}

This study offers only a selection of collection development strategies currently used by practitioners and is not exhaustive. Items included in the survey were ones we identified through the professional literature and ones we felt were most closely related to collection development and management practices. As a result, topics such as open access, centralized collection development, and newer preservation and wedding techniques. Further, the items listed on survey are not of equal weight some strategies play a larger role in collection management.

\section{Findings}

Four current collection development trends were included in nearly all curricula: Collaborative/cooperative collection development (100\%), participation in consortia and automation programs (97.1\%), and 'just-in-time' (JIT) or patron-driven acquisitions for either traditional or e-books (91\%). 


\begin{tabular}{lcc}
\hline $\begin{array}{l}\text { Table 1. Trends Discussed in Collection Development } \\
\text { Course Curricula }\end{array}$ & $\begin{array}{c}\text { Response } \\
\text { Count }\end{array}$ & $\begin{array}{c}\text { Percent } \\
\text { Response }\end{array}$ \\
\hline Collaborative/cooperative collection development & 35 & $100 \%$ \\
Participating in consortia and automation programs & 34 & $97 \%$ \\
Just-in-time or Patron-driven acquisitions for traditional or & 32 & $91 \%$ \\
e-books & 22 & $63 \%$ \\
Floating collections & 21 & $60 \%$ \\
Pay-per-view article acquisitions & 19 & $54 \%$ \\
Leaving “Big Deals" or reducing journal/serial subscriptions & 17 & $49 \%$ \\
Selecting paperback rather than hardback editions & 15 & $43 \%$ \\
How to seek donations and grants & 11 & $31 \%$ \\
A renewed emphasis on monograph rather than & & \\
journal/serial purchases & 6 & $17 \%$ \\
Acquisitions projects with non-library entities & & \\
\hline
\end{tabular}

Two participants offered that gifts and donations are part of their management course and another mentioned that all issues related serials are covered in another course. Likely, some of these topics may be covered in other courses, presenting a limitation for the study findings.

Survey respondents mentioned several other topics covered in their courses that reflect budget constraints, including: false advertising, bait and switch, ebooks and cell phone books, changes in publishing models, open access, centralized collection development, and public library privatization. And others not specifically related to the current economic situation, including malpractice, lost opportunity costs associated with weeding, and budget allocation mistakes.

In response to question four, with regards to how they use these topics in their classes, respondents listed student presentations, project based assignments, class discussions, and guest speakers. Projects involve case studies, creating policies, and what if scenarios. Two participants indicated that the two most current textbooks largely did not address the topics mentioned in the survey and that scholarly research articles were difficult to find on such topics as floating collections and vendor negations. Indeed, a review of collection development texts by Vicki L. Gregory and Peggy Johnson revealed that the trends are largely not mentioned in texts. Gregory's text, Collection Development and Management for $21^{\text {st }}$ Century Library Collections, mentioned just two trends: consortia and collaborative collection development. Johnson's Fundamentals of Collection Development and Management is slightly more comprehensive in its coverage of recent trends. It covered consortia and collaborative collection development, as well as acquisition projects with non-library entities. It also mentioned gifts and just-in-time collection development, though these trends were not discussed in a budgetary context. Indeed,

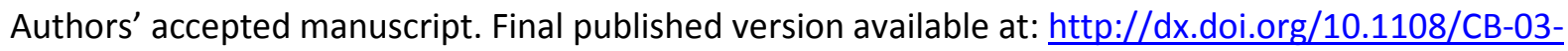
$\underline{2013-0012}$ 
as our participants indicated, the texts available for collection development cover few of the trends actually happening in collection development practice. The following response reflects several comments made on this topic,

"Many of these topics are covered during class discussions. There is no information about these topics available from typical textbooks. We use news articles, web resources, other materials to discuss such topics."

Several responses indicated that budgetary concerns pervaded the course. The following respondent addresses this point,

"Many of these topics are essential AND linked, so it's hard to describe one without getting into the others. One of the key assignments in the course is a collection assessment report in anticipation of a budget cut. This gives students a chance to look at many issues and to make considered recommendations."

Assignments described tended to show the interrelated nature of the issues. For example,

"There are a variety of projects that allow students to explore these issues. 1) Weeding and Selection - Investigating one area of the library and making weeding and selection recommendations based on the criteria set forth by a participating library. Students look at all available formats in developing final recommendations. 2) Create collection management policy that includes collaborative arrangements, monograph and serial acquisition, and just in time acquisition."

Cooperative or consortia based collection agreements, patron driven access, and reduction of serials were three topics receiving the most attention in the comments section. Fourteen of the respondents indicated they stressed cooperative collection building in their courses with half of those mentioning a project assigned specifically to address this topic in part or in full. Nine respondents stressed the need to cover PDA and JIT given the increased use of these methods in all types of libraries. Five respondents addressed the serials crisis through discussions on Big Deals, consortia agreements, licensing, and open access.

Several respondents emphasized both their and the students desire to have their courses reflect real life library practices. The use of guest speakers, adjunct professors, and full-time faculty that have experience with collection development issues were expressed as ways of ensuring this happens. Related to this, the importance of understanding vendor business practice was stressed. For example:

Authors' accepted manuscript. Final published version available at: http://dx.doi.org/10.1108/CB-03$\underline{2013-0012}$ 
"All these topics are central to collections work and I assign current readings that illustrate reallife examples of these issues in varying library types. The module on scholarly communication, for example, includes material on what the "Big Deals" are, how they came about, and the pitfalls and consequences of those licensing deals. I use real-life examples, including license agreements and spreadsheets used by libraries in determining duplicate coverage and cancellation possibilities. I also invite vendors to come speak to my students, so they can hear (and question!) another perspective."

\section{Discussion}

Our results indicate that strategies for collection development on a tight budget that have been adopted by libraries are somewhat addressed in the LIS curriculum, in particular, participation in consortia and automation programs and just-in-time (JIT) or patron-driven acquisitions for either traditional or e-books. Of the ten trends identified in the review of the professional literature, four were addressed by fewer than half of the educators surveyed. Our survey participants offered some explanations for why certain topics were not addressed, including subjects being covered in other courses. Additionally, a review of two collection development texts revealed that only three of the ten trends were discussed in a budgetary context ( $\mathrm{a}$ few others were mentioned but not in relation to budgets). It seems that there is a disconnect between what is being taught in collection development courses and mentioned in collection development texts and what actually occurs in libraries around the country.

Similarly, there has been a lack of guiding standards from professional organizations. As a result, practitioners and educators alike are left with little to refer to when collection development practices come into question. Instead, they may turn to the LIS literature. This, however, could also be problematic as the literature best represents academic libraries and has little information about collection development and budgetary trends in public or school libraries.

Hopefully, this research will increase awareness amongst LIS educators of current trends, not well represented in either collection development texts or professional standards. Indeed, one participant stated, "JIT collections is being added to this class next time I teach it" while another indicated they were not aware of the trend of placing "renewed emphasis on book collections" rather than serial subscriptions, as outlined by Walters (2008).

\section{Conclusions}

This study examined professional standards, collection development texts, and the LIS literature as well as surveying current collection development educators in an effort to assess

Authors' accepted manuscript. Final published version available at: http://dx.doi.org/10.1108/CB-03$\underline{2013-0012}$ 
whether or not current practices in collection development are addressed in those areas. The rewriting of ALA's Guide to Collection Development Policy Statements by the RUSA CODES Collection Development Planning, Education \& Assessment Committee and the present research will hopefully work to foster connections between professional standards, professional practice, and LIS education.

Authors' accepted manuscript. Final published version available at: http://dx.doi.org/10.1108/CB-03$\underline{2013-0012}$ 


\section{References}

Church, A., Dickinson, G., Everhart, N., \& Howard, J. (2012), “Competing standards in the education of school librarians", Journal of the Education for Library and Information Science, Vol. 53 No. 3, pp. 208-217.

Collins, P. (2012), "Fear and loathing in cooperative collection development", Interlending $\mathcal{E}$ Document Supply, Vol. 40 No. 2, pp. 100-104.

Everhart, N. \& Dresang, E. (2007), “Integrating research results and National Board Certification Standards into a leadership curriculum for school library media specialists", Journal of the Education for Library and Information Science, Vol. 48 No. 4, pp. 271-283.

Fisher, E. S., Kurt, L., \& Gardner, S. (2012), “Exploring patron-driven access models for ejournals and e-books", Serials Librarian, Vol. 62 No. 1-4, pp. 164-168.

Herrera, G. (2012), "Deliver the ebooks your patrons and selectors both want! PDA program at the University of Mississippi", Serials Librarian, Vol. 63 No. 2, pp. 178-186.

Johal, J., Quigley, T., Bartlett, W., Kressler, T., Gafiney, J., Bartel, C., and Cropper, D. (2012), “Take the plunge! Implementing floating collections in your library system", Public Libraries, Vol. 51 No. 3, pp. 13-20.

Kieft, R., and Payne, L. (2012), “Collective collection, collective action”, Collection Management, Vol. 37 No. 3/4, pp. 137-152.

Lester, J. \& Van Fleet, C. (2008), “Use of professional competencies and standards documents for curriculum planning schools of library and information studies education", Journal of the Education for Library and Information Science, Vol. 49 No. 1, pp. 43-69.

Mon, L., Abels, E. G, Agosto, D. E., Japzon, A., Most, L., Masnik, M., \& Hamann, J. (2008), "Remote reference in U.S. public library practice and LIS education", Journal of Education for Library and Information Science, Vol. 49 No. 3, pp. 180-194.

Nous, R., and Roslund, M. (2009), "Public library collaborative collection development for print resources", Journal of the Library Administration \& Management Section, Vol. 5 No. 3, pp. 5-14.

Authors' accepted manuscript. Final published version available at: http://dx.doi.org/10.1108/CB-03$\underline{2013-0012}$ 
Pan, D., and Fong, Y. (2010), "Return on investment for collaborative collection development: a cost-benefit evaluation of consortia purchasing", Collaborative Librarianship, Vol. 2 No. 4, pp. 183-192.

Sammonds, L. (2012), "Sustainable collections: the pay-per-view model”, Serials Librarian, Vol. 63 No. 2, pp. 173-177.

Schroeder, R. (2012), "When patrons call the shots: patron-driven acquisition at Brigham Young University", Collection Building, Vol. 31 No. 1, pp. 11-14.

Schroeder, R., and Wright, T. (2011), "Electronic books: a call for effective business models", New Library World, Vol. 112 No. 5/6, pp. 215-221.

Sproles, C., Johnson, A., and Farison, L. (2008), "What the teachers are teaching: How MLIS programs are preparing academic librarians for instructional roles," Journal of Education for Library and Information Science, Vol. 43 No.3, pp. 195-209.

Walters, W.H. (2008), “Journal Prices, Book Acquisitions, and Sustainable College Library Collections", College $\mathcal{E}$ Research Libraries, Vol. 69, No. 6, pp. 576-586. 


\section{Appendix One: Survey}

1. How long have you taught collection development related courses?

2. Have you worked as a practicing librarian?

a. If yes, for how long and in what capacity?

3. Does your curriculum include discussion of any of the following? (Select all that apply)

a. Floating collections

b. Collaborative/cooperative collection development

c. A renewed emphasis on monograph rather than journal/serial purchases

d. Selecting paperback rather than hardback editions

e. How to seek donations and grants

f. Acquisitions projects with non-library entities

g. Pay-per-view article acquisitions

h. Just-in-time or Patron-driven acquisitions for traditional or e-books

i. Participating in consortia and automation programs

j. Leaving “Big Deals" or reducing journal/serial subscriptions

4. If you selected any of the above trends related to the internal and external economic hardships libraries are facing, please describe one (or more) example(s) of how and why the topic is addressed in your class:

5. Any additional comments?

6. You may leave your name and contact information below. This will help us track survey return rates and is entirely voluntary. 